\title{
Perspectivas da psicologia junguiana acerca da religião
}

\author{
Jungian psychology perspectives on religion
}

\author{
Luiz Henrique Lemos Silveira* \\ Paulo Ferreira Bonfatti**
}

\begin{abstract}
Resumo
Observa-se que o fenômeno da religião é algo extremamente complexo e muitas áreas do conhecimento acadêmico têm se dedicado há muito tempo a tentar compreendê-lo sem, contudo, esgotá-lo. Dentre as diversas áreas, a psicologia tem se apresentado nessas tentativas de entendimento com seus diversos referenciais teóricos. Nas diversas ramificações da psicologia, a perspectiva teórica junguiana tem se mostrado com uma privilegiada interface e interessante chave de compreensão, muito produtiva em relação à religião. Todavia, essa teoria psicológica tem sido, de forma superficial e incompreendida, considerada como uma teoria psicológica unilateralmente a favor da religião - o que definitivamente não é verdade. Assim sendo, através de uma tentativa de elucidação de alguns conceitos e concepções junguianas acerca da psique, esse artigo tem como objetivo apontar não só o posicionamento epistemológico de neutralidade dessa teoria como também apresentar a importância psicológica da religião enquanto criação psicológica humana que contribui, por vezes negativa e por outras positivamente, para o processo de crescimento psicológico conhecido como individuação.
\end{abstract}

Palavras-chave: religião; Jung; psicologia; psicologia junguiana; individuação.

\begin{abstract}
It is observed that the phenomenon of religion is something extremely complex and many areas of academic knowledge have long been trying to understand it without, however, exhausting it. Among the different areas, psychology has been present in these attempts to understand with its various theoretical references. In the various ramifications of psychology, the Jungian theoretical perspective has been shown with a privileged interface and interesting key to understanding, very productive in relation to religion. However, this psychological theory has been superficially misunderstood as a psychological theory unilaterally in favor of religion - which is definitely not true. Therefore, through an attempt to elucidate certain Jungian concepts and conceptions about the psyche, this article aims to point out not only the epistemological position of neutrality of this theory but also to present the psychological importance of religion as a human psychological creation that contributes, for negative and sometimes positively, to the process of psychological growth known as individuation
\end{abstract}

Keywords: religion; Jung; psychology; Jungian Psychology; individuation.

Artigo submetido em 15 de abril de 2019 e aprovado em 12 de agosto de 2019.

* Doutor em Psicologia pela PUC Minas. Professor da Faculdade Pitágoras Teixeira de Freitas. País de origem: Brasil. E-mail: luizhls@yahoo.com.br

** Doutor em Psicologia Clínica pela PUC-Rio. Professor do CES/JF. País de origem: Brasil. E-mail: paulobonfatti@hotmail.com 


\section{Introdução}

São muitas as possibilidades e tentativas de se compreender a religião e a Psicologia é apenas uma delas. Além disso, diversas são as abordagens psicológicas sobre o tema da religião e o que se pretende é tentar apontar as contribuições da teoria psicológica de Carl Gustav Jung para esse tema.

Tal tentativa se justifica pelo fato de haver uma visão limitada, que se repete muitas vezes tanto dentro quanto extra campo acadêmico, numa superficial perspectiva de que a psicologia junguiana seria uma teoria psicológica a favor das religiões.

Dentro desse contexto, esquece-se que o ponto de vista junguiano é do ponto de vista psicológico e não pessoal e, por isso, há um equívoco ingênuo em se confundir o pesquisador com seu objeto de investigação. Ou seja, simploriamente, entende-se que o motivo de Jung ter se dedicado a estudar a religião é devido ao fato dele ser a favor da religião ou até mesmo, religioso.

O que se pode depreender é que Jung foi um dos primeiros pesquisadores da psicologia que se dedicou, compreensivamente, a estudar as religiões. O que, desde o início, causou certo estranhamento não só dentro de um zeigeist cientificista e cartesiano de sua época como também por não possuir um viés exclusiva e unilateralmente negativo ou patológico sobre o assunto.

Assim, para tentar clarificar esses equívocos que esse artigo propõe trazer à luz algumas contribuições acerca da psicologia junguiana sobre da religião, entendendo desde já que seu autor não busca uma postura de ser nem a favor e nem contra a mesma. De mais a mais, dentro da neutralidade de pesquisador, Jung se foca exclusiva e epistemologicamente à dimensão psicológica da religião e a entende, somente, como criação humana e não como uma dimensão revelada ou metafísica. 
Dentro desse esforço, se proporá que no conceito de arquétipo e seu corolário, inconsciente coletivo, Jung propõe compreender a religião integrando-a a sua concepção da psique. Mais que isso, por vezes, também encontra na religião uma função psíquica que viabiliza a elaboração e integração de conteúdos psíquicos que levam a um crescimento psicológico.

Assim sendo, tem-se como expectativa levar o leitor a uma maior compreensão não só da teoria junguiana, mas também da visão dessa teoria em relação a um fenômeno tão significativo quanto complexo que é a religião.

\title{
1 Religião como expressão psíquica
}

As palavras de Jung, abaixo, já evidenciam de que posição ele parte para abordar a religião em sua teoria, isto é, como psicólogo, e não como um religioso ou teólogo.

\begin{abstract}
Abordo os fatos psicológicos, não sob um ângulo filosófico, mas de um ponto de vista científico-natural. Na medida em que o fenômeno religioso apresenta aspecto psicológico muito importante, trato o tema dentro de uma perspectiva exclusivamente empírica: limito-me, portanto, a observar os fenômenos e me abstenho de qualquer abordagem metafísica ou filosófica. Não nego a validade de outras abordagens, mas não posso pretender a uma correta aplicação destes critérios. (JUNG, 1988 p. 1-2).
\end{abstract}

Entretanto, este interesse de Jung pelo tema da religião foi mal recebido por muitos críticos, acusando-o, muitas vezes, de místico ou de abordar temas metafísicos ao assunto da religião. Mesmo que ele se atentasse para temas da religião de cunho institucional, sua análise a estes, era pelo viés da Psicologia, entendendo-as como uma experiência arquetípica. Conforme Clarke:

Críticos de Jung insistem em acusá-lo de todos os tipos de obscuridades místicas e metafísicas, em especial no tocante a suas notórias excursões nas tradições místicas e ocultistas. Parece-lhes que ele se deu ao luxo de adotar extravagantes crenças pré-científicas de todos os tipos de fontes, orientais e ocidentais, cristãs e pagãs, enquanto que, ao mesmo tempo, reclamava o status de cientista. (CLARKE, 1993, p. 58). 
Assim, Jung, vincula-se ao aspecto psicológico, contudo, sem desqualificar as formas metafísicas e filosóficas de marcando epistemologicamente, sua área de atuação. A Psicologia, em sua especificidade, lida com a religião como uma criação psíquica humana. Por isso, a análise junguiana da religião surge a partir da psicologia e não da teologia, filosofia, metafísica ou pela análise da religião institucional. (JUNG, 1988).

A perspectiva de Jung resgata a palavra religião do latim religere e também de re-ligare. O termo religere vem da etimologia de religio, baseando-se em postulações de teóricos Antigos, como assertivas de Cícero. Há, Também, outra análise, judaico-cristã, da palavra religio, que deriva de religare, cujo significado é "unir", "religar”. Jung adota a interpretação de religio como religare, pois este autor apropria-se da concepção de Otto de numinoso. É importante destacarmos que esta escolha de Jung se deve à ideia que o mesmo tem sobre o termo religare, que envolve característica do aspecto numinoso que é fundamental para o entendimento que ele tem da religião, como uma experiência psíquica arquetípica. Contudo, há uma diferença na análise do numinoso de Otto e de Jung. O primeiro, entende a partir da Teologia numinoso como uma análise dos aspectos racionais e irracionais da religião (OTTO, 1992), já o segundo dá um significado psicológico, enfatizando a experiência arquetípica impactante ao ego (JUNG, 1988).

Para Jung, o termo religião não se refere a uma determinada profissão de fé religiosa. Para ele, “[...] designa a atitude particular de uma consciência transformada pela experiência do numinoso" (JUNG, 1988, p. 4). Assim, Jung não se refere a qualquer credo ou igreja em particular, seu interesse está na atitude religiosa como função psíquica; é a experiência religiosa como processo psíquico e experiência arquetípica.

Jung (1988) aproximou-se do conceito de Otto de numinoso para referir-se aos arquétipos. Para Jung, o aspecto numinoso tem uma relação direta com o processo psíquico da experiência arquetípica. 
Baseando-se em Otto, Jung afirma que a experiência do numinoso provoca uma modificação especial na consciência, e compara o contato com a presença ou o objeto numinoso ao confronto do indivíduo, da consciência, com os conteúdos do inconsciente. Tratar-se-ia basicamente das imagens arquetípicas procedentes do arquétipo. (RICHTER, 2005, p. 24).

Portanto, podemos afirmar que são pelas características numinosas, presentes na experiência arquetípica, que Jung identifica ligações entre a experiência arquetípica e a religião. Aponta que a religião como uma expressão da experiência arquetípica por referir-se ao efeito numinoso. (JUNG, 1988).

Os aspectos principais do arquétipo seriam sua numinosidade, inconsciência e autonomia. $\mathrm{O}$ contato com as imagens de origem arquetípica proporcionaria fascínio e temor conduzindo assim o ser humano à experiência primordial. (SILVEIRA, 1981, p. 24).

Podemos identificar que estas características de fascínio e temor, presente no contato do ego com as experiências arquetípicas, também são semelhantes às características que Otto (1992) nomeia como experiência numinosa do Sagrado, tremedum et fascinans. Dessa maneira, sendo a experiência religiosa uma experiência arquetípica e numinosa,

os sistemas religiosos recolhem e conservam imagens simbólicas oriundas do inconsciente, elaborando-as em seus dogmas, estabelecendo assim conexões com as estruturas básicas da vida psíquica. As confissões religiosas seriam formas codificadas e dogmatizadas de experiências religiosas primordiais. (SILVEIRA, 1981, p. 43).

Jung compreende que determinada confissão religiosa surge, a princípio, a partir de dois aspectos, "por um lado, se funda, originalmente, na expressão do numinoso, e por outro, na pistis, na fidelidade (lealdade), na fé e na confiança em determinada experiência de caráter numinoso e na mudança de consciência que daí resulta” (JUNG, 1988, p. 4). Dessa forma, um

grande número de práticas rituais são executadas unicamente com a finalidade de provocar deliberadamente o efeito numinoso, mediante certos artifícios mágicos como p. ex. a invocação, a encantação, o sacrifício, a meditação, a prática do ioga, mortificações voluntárias de diversos tipos, etc. (JUNG, 1988, p. 3). 
Portanto, na visão de Jung (1988), as confissões religiosas são formas dogmatizadas das experiências psicológicas, nas quais estas foram sacralizadas e organizadas em uma construção mental para adquirirem conotações e serem simbolizadas, com finalidade de conscientização. Tais construções ocorreram através de várias repetições, ao longo dos tempos. Assim as confissões religiosas podem desempenhar uma função mediadora entre o ego e sua experiência arquetípica imediata, através de símbolos que se observam em seus dogmas e rituais (JUNG, 1988).

Segundo Jung (1988), a ocorrência de diversas repetições das experiências originais, durante os vários séculos da humanidade, fez com que estas experiências se transformassem em ritos e instituições quase imutáveis. Desse modo, os ritos e as instituições representam formas de experiências religiosas para várias pessoas. Jung propõe que vários rituais teriam sido transformados em dogmas para conservarem os processos simbólicos das experiências psíquicas primordiais. Então, os dogmas seriam expressões de base psicológica arquetípica, seria uma elaboração arquetípica de uma necessidade coletiva. Nesse sentido, ele explica:

O que geralmente se chama de "religião" constitui um sucedâneo em grau espantoso que me pergunto seriamente se esse tipo de religião - que prefiro chamar de "confissão" - não desempenha uma importante função na sociedade humana. Ela tem a finalidade evidente de substituir a experiência imediata por um grupo adequado de símbolos envoltos num dogma e num ritual fortemente organizado. (JUNG, 1988, p. 48).

Jung (1988) afirma que os dogmas e os rituais religiosos servem como uma forma de símbolos para intermediar às experiências arquetípicas imediatas, pois quando estas experiências surgem de forma direta para consciência do ego, sem ser simbolizadas, acarretam em ameaças à integridade do ego. Ademais, observou, em diversos casos clínicos, pessoas com convicções religiosas que, ao recorrerem a certos símbolos ou a dogmas e rituais religiosos, se protegiam das experiências imediatas arquetípicas. 
É nesse contexto que Jung (1998) tem uma visão psíquica funcional das religiões (dogmas e rituais), ao perceber que elas organizam símbolos capazes de proteger o ego das experiências arquetípicas. Nesta perspectiva, Jung afirma que, enquanto tal experiência for eficaz, não é passível de críticas, entendendo que esta modalidade de experiência pode ser útil ao processo de desenvolvimento da personalidade do indivíduo, ou seja, ao processo de individuação ${ }^{1}$.

Na visão de Silveira (1981), Jung apresenta uma atitude positiva sobre as religiões: "Todas são válidas na medida em que recolhem e conservam as imagens simbólicas oriundas das profundezas do inconsciente e as elaboram em seus dogmas, promovendo assim conexões com as estruturas básicas da vida psíquica”. (SILVEIRA, 1981, p. 153). Mas, em contrapartida, Jung relata que podem também ser prejudiciais ao crescimento psicológico, se a experiência religiosa do indivíduo caracterizar um processo infantilizante ou psicotizante, quando não há uma assimilação do ego, ocorrendo uma invasão arquetípica. (JUNG, 1988).

Assim, Jung (1988) identifica que os dogmas, rituais e as religiões, podem proporcionar uma possibilidade de simbolização das experiências arquetípicas, proporcionando ao ego a possibilidade de entrar em contato com inconsciente. Por outro lado, há também numa não simbolização a possibilidade de uma invasão arquetípica numa dinâmica psicopatológica.

Para Jung (1988), há uma relação entre o dogma e a psique, na qual o dogma religioso constitui-se numa representação simbólica, de base arquetípica. Assim, quando Jung busca compreender os fenômenos religiosos, faz uma leitura psicológica de tais fenômenos e pretende reencontrar a ligação dos dogmas religiosos com as imagens imediatas do arquétipo, a partir da análise dos símbolos do inconsciente.

\footnotetext{
${ }^{1}$ Por individuação, Jung entende um processo, um "vir a ser", isto é, uma possibilidade de desenvolvimento do indivíduo, não algo estático e definitivo, mas um processo continum que nunca se encerra ou se conclui, de modo que se desenrola durante uma vida inteira e jamais é completado.
} 
Segundo Jung (1988), há dois tipos de símbolos, os naturais e os culturais. Os símbolos de características naturais são imagens arquetípicas de conteúdos que surgem do inconsciente, independentemente, da consciência do indivíduo, ou seja, o inconsciente cria símbolos que abrangem todos os aspectos da natureza humana que se arraigaram, ao longo dos tempos, nas diversas representações coletivas do homem. Por sua vez, os símbolos de características culturais são considerados “verdades eternas” presentes nas religiões, mas que passaram por modificações realizadas pela atividade consciente, tornando-se assim representações coletivas. Isso não significa, necessariamente, que eles perdem suas características de representação simbólica, pois estas podem continuar vivas e sua numinosidade ser mantida.

Nessa perspectiva, Jung (1988) afirma que os processos psíquicos arquetípicos possuem características numinosas, e que para se tornarem acessíveis para a compreensão e percepção do ego, e assim proporcionem ao mesmo a possibilidade que se desenvolva e individue, ele necessita de símbolos que façam a intermediação do confronto dos conteúdos inconsciente com os fatores conscientes do ego. Pois o ego, ao entrar em contato com os fatores inconscientes sem uma intermediação do símbolo, terá sérios prejuízos em sua integridade. Assim, a função do símbolo seria a de permitir que o ego se depare com os fatores arquetípicos do inconsciente, sem que ocorra comprometimento à sua integridade.

De acordo com Jung (2011) é pela elaboração do ego dos conteúdos inconscientes, via processo simbólico que acontecerá processo natural que não colocaria em perigo a sua integridade. Assim, para que aconteça esta elaboração do ego dos fatores inconscientes faz-se necessário que ocorra uma integração dos fatores racionais e irracionais.

Deste modo, o homem que possui uma forma simbólica por meio da religião pode, através dela, assimilar seus conteúdos psíquicos trazendo-os para consciência por meio do processo de simbolização. Dessa maneira as confissões religiosas evocam em suas vivências o aspecto arquetípico que através de seus 
dogmas, ritos e rituais podem desempenhar uma função mediadora (simbólica) entre o indivíduo e sua experiência arquetípica imediata, pois a experiência imediata, através do processo de simbolização, permite a aproximação entre a consciência e as manifestações arquetípicas que procedem do inconsciente. (JUNG, 1988).

Cumpre deixar claro aqui, que assim sendo, a partir do aspecto simbólico presente nos rituais religiosos, a religião se torna uma possibilidade, um caminho para que ocorra o processo de individuação, através da sua organização e oferta simbólica, contudo ela não é o único caminho. A religião não é uma panaceia; ela é, apenas, uma das diversas possibilidades simbólicas para que não ocorra a desintegração do ego, diante do efeito numinoso do arquétipo. Caso fosse essa perspectiva equivocada, em que a religião seria a solução para o processo de individuação, os ateus não incorreriam, nesse processo de crescimento psicológico, o que é absolutamente incorreto! Mais, ainda, nessa linha de raciocínio, todas as pessoas ditas religiosas estariam em franco processo de individuação, o que também seria, igualmente, incorreto.

Portanto, podemos afirmar que a análise proposta por Jung sobre os mitos, ritos e religiões são formas que o homem expressa de maneira protegida, de forma simbólica, vivências e experiências passadas de caráter arquetípico, como também as que estão vivenciando, no presente. Nesta mesma direção, Richter (2005) aponta que tanto o mito quanto o rito possuem significado terapêutico.

Assim, Jung (1988) vê a importância dos mitos e ritos como um processo de simbolização de conteúdos do inconsciente e observa que há possibilidade das confissões religiosas constituírem, de certo modo, uma espécie de "cura religiosa". Ele aponta que alguns ritos, mitos e religiões, na pior das hipóteses, funcionariam como "métodos de higiene". Isso quer dizer que, por meio de alguns rituais e mitos, as pessoas com disposição religiosa, se protegem das experiências arquetípicas; diferentemente daquelas que não dão importância às questões religiosas ou a qualquer outro meio como processo simbólico para se proteger de conteúdos do 
inconsciente. Isto não se quer dizer que todas as pessoas tenham de ter uma religião para serem saudáveis psiquicamente. A importância da religião, aqui, é vista como simbólica e serve como proteção da experiência arquetípica que é numinosa. Muitas pessoas que não têm religião podem utilizar-se de outras práticas e costumes como forma de simbolização.

Por outro lado, mais uma vez, Jung também faz uma crítica da religião quando ela não é utilizada como processo simbólico, mas como forma de expressão, que conduz para uma alienação. (JUNG, 1988) Assim, a religião tornase, extremamente, prejudicial ao desenvolvimento do ego e, consequentemente, inviabiliza o processo de individuação. Podemos observar estas características nos tipos de fundamentalismo que aliena o indivíduo.

Nesta direção, percebemos que a visão que Jung tem sobre a religião está relacionada à experiência psicológica arquetípica e não enquanto religião confessional/Institucional. Esta, enquanto uma forma de expressão simbólica será fundamental para o desenvolvimento psicológico do indivíduo, mas também pode se tornar um campo privilegiado de psicopatologias, quando não exerce uma função simbólica. (JUNG, 1988).

Assim, podemos identificar que as várias experiências arquetípicas vivenciadas pela humanidade, nas quais estão presentes nos mitos, os dogmas, rituais e nas religiões são formas que evocam os conteúdos arquetípicos, que quando simbolizadas protegem o ego à exposição direta destas experiências, e também o proporciona a possibilidade de perceber estes conteúdos arquetípicos e assimilá-lo e, consequentemente, gera uma nova consciência e desenvolvimento do ego permitindo-o uma progressão no processo de individuação. Contudo, se o ego não assimilar estes símbolos podem conduzi-lo a um estado de desorientação mental, proporcionando-o psicopatologias que inviabilizam o seu desenvolvimento, e consequentemente compromete o processo de individuação; já que a individuação requer a assimilação do ego dos conteúdos inconsciente e assim para ter uma nova consciência. (JUNG, 1988). 


\section{Os símbolos religiosos como expressão do si-mesmo}

Como vimos, a perspectiva junguiana sobre a religião parte do foco da experiência psicológica arquetípica através do símbolo que vai intermediar o ego com as instâncias inconscientes - pois o símbolo cumpre o papel de ponte entre a consciência e o inconsciente. É através dele que se viabiliza ao ego entrar em contato com o si-mesmo (conhecido também como Self ou Selbst) e, por conseguinte, ter um novo estado de consciência que é fundamental para a individuação. Desse modo, como a meta é a individuação, o si-mesmo possui a capacidade de gerar símbolos que permitem que o ego tenha consciência dos fatores do inconsciente tanto pessoal e coletivo, conduzindo, consequentemente, ao processo de individuação. (JUNG, 1986).

Jung identifica o Si mesmo, por excelência como o arquétipo central e da totalidade, e tende atrair todos os outros arquétipos em torno de si. "Psicologicamente, o si-mesmo foi definido como a totalidade psíquica do homem, ou seja, tudo aquilo que o homem supõe constituir, de per si, uma totalidade mais ampla, pode tornar-se símbolo do si-mesmo" (JUNG, 1988, p. 156). Nesta mesma direção, este autor relata que

o si-mesmo não é apenas um conceito abstrato, ou um postulado lógico, mas uma realidade psíquica que só é consciente até certo ponto, abrangendo também a vida do inconsciente, razão pela qual não é diretamente perceptível à observação, só podendo exprimir-se em símbolos. (JUNG, 1988, p. 157).

Deste modo podemos observar o simbolismo do si-mesmo presente em diversas culturas, mitos, ritos, tradições religiosas e, principalmente na representação da divindade, pois conforme Jung (1986) esta é um receptáculo privilegiado para representação do si-mesmo. Jung entende que: 
Seria uma blasfêmia afirmar que Deus pode manifestar-se em toda parte, menos na alma humana. Ora, a intimidade da relação entre Deus e a alma exclui de antemão toda e qualquer depreciação desta última. Seria talvez excessivo falar de uma relação de parentesco; mas, de qualquer modo, deve haver na alma uma possibilidade de relação, isto é, forçosamente ela deve ter em si algo que corresponda ao ser de Deus, pois de outra forma jamais se estabeleceria uma conexão entre ambos. Esta correspondência, formulada psicologicamente, é o arquétipo da imagem de Deus [e não Deus]. (JUNG, 1991, p. 23 grifo do autor).

O símbolo da totalidade, o si-mesmo, é representado em nível coletivo, mais especificamente, nas religiões monoteístas, como figura de Deus, que está presente no Cristianismo, Judaísmo e Islamismo. A representação simbólica do si-mesmo está contido nas religiões como imago dei - imagem psicológica de Deus, e não Deus - como símbolo da totalidade. Sobre tal representação, Jung relata:

Não me parece de todo improvável que o arquétipo da totalidade possua, como tal, uma posição central que o aproxime singularmente da imagem de Deus. Esta semelhança é ainda confirmada, em particular, pelo fato de este arquétipo criar um simbolismo que sempre serviu para caracterizar e exprimir imagisticamente a divindade. Estes fatos tornam possível uma limitação do sentido de nossa afirmação feita acima, sobre o caráter indiferenciável da imagem de Deus e do inconsciente: a imagem de Deus não coincide propriamente com o inconsciente em si, mas com um conteúdo particular deste último, isto é, com o arquétipo do si-mesmo. (JUNG, 1988, p. 471).

Para Jung (1988), há sempre uma imagem da totalidade ou do si-mesmo que é representada, nas mais diversas experiências religiosas, pela imago dei. Assim como o si-mesmo possui o caráter ordenador, também a imago dei exerce a função ordenadora destas experiências. Esta ordenação viabiliza a simbolização da experiência, para que assim se tenha conscientização dos elementos inconscientes. Como visto, a experiência religiosa emana do inconsciente, apresentando-se de forma numinosa à psique, por ser constituída de uma experiência arquetípica. Por isso, percebemos uma relação entre o si-mesmo e a imago dei nas experiências religiosas.

Desse modo, observamos que o ego ao entrar em contato com a experiência arquetípica, através da representação simbólica do si-mesmo, vivencia uma experiência numinosa e transcendental do ponto de vista psicológico do ego, e não 
metafísico, que permite que ele tenha assimilação dos conteúdos arquetípicos; já que o símbolo do si-mesmo possui aspecto de centro, totalidade e ordenação. Desse modo, compreendemos que a imago dei, nas representações religiosas, possui esta característica, já que esta é uma forma de representação do si-mesmo. (JUNG, 1988).

Portanto, mais uma vez, entendemos a importância que Jung dá às religiões, por identificar que há, no contexto simbólico religioso uma representação do simesmo, a partir da imagem de Deus (imago dei) que se apresenta como símbolo da totalidade, uma vez, que este possui o caráter de ordenar todos os processos psíquicos. Jung afirma:

$\mathrm{Na}$ maioria das formas de misticismo a experiência mística central aparece simbolizada, com justeza, pela luz. É estranhamente paradoxal que o aproximar-se de uma região que parece um caminho que nos leva à escuridão tenha por resultado a luz da iluminação. Mas trata-se aqui da usual enantiodromia [transformação no contrário] "per tenebras ad lucem" (à luz através das trevas). Em muitas das cerimônias de iniciação, efetua-se uma [...] (descida à caverna), um mergulho nas profundezas da água batismal ou uma volta ao seio materno onde se dará o novo nascimento. O símbolo do novo nascimento descreve tão somente a união dos contrários - consciente e inconsciente - mediante analogias de caráter concretista. Qualquer simbolismo do novo nascimento tem como base a função [psíquica] transcendente. Como esta função leva a um aumento do grau de consciência reflexa (acrescentando-se os conteúdos anteriormente inconscientes ao estado precedente), este novo estado acarreta um maior grau de luz. Trata-se, portanto, de um estado iluminado, em relação à relativa obscuridade do estado anterior. Em inúmeros casos a luz aparece até mesmo sob a forma de visões. (JUNG, 1988, p. 514).

Nesta mesma linha de raciocínio, Jung (1988) acrescenta que o si-mesmo possui em si, a característica de função transcendente, ou seja, uma característica psicológica e não metafísica que permite a intermediação do confronto dos opostos (consciente versus inconsciente), que atua com objetivo de resolver os conflitos existentes, entre consciente e inconsciente e, assim proporcionando que o ego tenha uma nova percepção. Esta nova consciência do ego conduz a um processo de transformação na atitude consciente do indivíduo, direcionando-o à individuação. Portanto podemos pensar a função transcendente como aspecto do si-mesmo. Nesse sentido, Jung relata: 
O espírito entendido como "instrumento para se atingir a outra margem" indica uma ligação entre a função transcendente e a ideia de espírito ou de si-mesmo. Como a natureza incognoscível do espírito, isto é, do inconsciente, sempre se apresenta à consciência sob forma de símbolos o si-mesmo é um destes símbolos -, o símbolo funciona como "instrumento para atingir a outra margem", ou, dito em outras palavras, é um instrumento de transformação. (JUNG, 1988, p. 508).

Entendemos, portanto, que o si-mesmo, através da imago dei, constitui-se como o centro e a totalidade de tudo que existe psiquicamente, assim, não haveria limite para ele, pois estaria em todo lugar. Portanto, Jung entende a imagem de Deus (imago dei), como um símbolo de centro e totalidade, como representação do si-mesmo. "Tudo o que se diz sobre a imagem de Deus pode ser aplicado sem nenhuma dificuldade aos símbolos da totalidade”. (JUNG, 1986, p. 30).

Em relação ao Cristianismo, Jung se interessa pelo simbolismo de Deus e Cristo vinculando-o ao símbolo da totalidade, ou seja, do si-mesmo. Ele não está interessado na perspectiva teológica, ou na existência ou não de Deus e Cristo, mas nas representações destes, enquanto imagens arquetípicas ou símbolos. Desse modo, entendendo que, na nossa civilização Ocidental, a figura de Cristo exerce a função de divindade (figura de Deus), este se torna uma representação da imagem de Deus, e, consequentemente, da imago dei e da totalidade do si-mesmo. "Cristo é para nós a analogia mais próxima do si-mesmo e de seu significado”. (JUNG, 1986, p. 30). Desse modo, podemos identificar que é possível fazermos uma relação de Deus e de Cristo com o símbolo do si-mesmo, pois "a imagem tradicional de Cristo engloba as características de um arquétipo que no caso, são idênticas as do simesmo”. (JUNG, 1986, p. 64). De acordo com Richter,

O si-mesmo, arquétipo universal, presente em todas as épocas, muitas vezes se encontraria afastado do âmbito da consciência, como se estivesse sido relegado ao esquecimento, ou jamais percebido. A partir de uma leitura que compara os símbolos do si-mesmo a imagens divinas, Jung afirma que, a medida que ocorre uma aproximação entre consciência e simesmo, podemos pensar no restabelecimento de um estado original, representado pela união com a imagem divina. Em termos psicológicos, tratar-se-ia de uma integração de aspectos diferentes e conflitantes da personalidade. A superação desta cisão pode ser representada a partir da emergência da figura [arquetípica] de Cristo na consciência humana. (RICHTER, 2005, p. 77). 
Assim, podemos perceber que o simbolismo do si-mesmo, ao estar representado pela figura de Deus e de Cristo torna-se importante para psicologia do crente cristão, pois representaria uma forma simbólica da expressão do simesmo. Jung ilustra que o símbolo de Deus e de Cristo como representação do simesmo, está contido não apenas numa perspectiva cristã, mas também no simbolismo alquímico. Neste, a figura de Deus e de Cristo apresenta-se como forma de peixes, pedra filosofal ou “lapisphilosophorum”. Sobre isso, Jung afirma:

O paralelo que acabo de traçar entre Cristo e o si-mesmo não é senão um tema psicológico, mais ou menos semelhante ao mitológico, em que se emprega a figura do peixe. Não se trata aqui, absolutamente, de uma ingerência no campo da Metafísica, isto é, no domínio da fé. As imagens que a fantasia religiosa constrói a respeito de Deus e de Cristo são inevitável e declaradamente antropomórficas e, por isto mesmo, acessível a uma radioscopia psicológica, como quaisquer outros símbolos. Assim como a Antiguidade clássica acreditava expressar alguma coisa a mais, a respeito de Cristo, com o símbolo do peixe, assim também os alquimistas estavam convencidos de que, ao colocá-lo em paralelo com a pedra, esclareciam e aprofundavam a imagem de Cristo; do mesmo modo que o símbolo do peixe viria a desaparecer no decurso do tempo, assim ocorreu com o "lapisphilosophorum" [a pedra filosofal]. (JUNG, 1986, p. 63)².

Tanto pela perspectiva cristã quanto em outras formas de representações religiosas, o si-mesmo pode ser comparado à imago dei. Assim as figuras de Deus e Cristo, tanto no Cristianismo, quanto na Alquimia, são considerados como símbolos do si-mesmo. Mas isso não quer dizer que o si-mesmo tome o lugar de Deus, e sim que ele seria um receptáculo de uma possível graça divina, através de experiências arquetípicas da imago dei. Como visto aqui, Jung atenta-se ao aspecto psicológico; e esta análise em nada interfere no âmbito metafísico de Deus, existindo ele ou não. (JUNG, 1988).

Podemos identificar a representação da imago dei no Cristianismo através da figura de Cristo. Todavia, ao entendemos como uma representação do simesmo, ou seja, a totalidade psíquica como uma experiência arquetípica que deveria conter em si na encarnação de Deus, tanto atributos do Cristo quanto do Anticristo, atributos do bem e do mal que representam esta totalidade. Contudo, o

\footnotetext{
${ }^{2}$ Ver nos livros Aion: estudos sobre o simbolismo do si-mesmo (JUNG, 1986) e Psicologia e alquimia (JUNG, 1991) mais detalhes a respeito da figura de Deus e de Cristo como representações do si-mesmo, e como símbolos do peixe e lapisphilosophorum na alquimia.
} 
Cristianismo tem dificuldade com a possibilidade da integração dos opostos. (JUNG, 1986). Segundo Richter (2005, p. 81) “[...] ao traçar um paralelo entre a figura tradicional de Cristo e o fenômeno psíquico do si-mesmo, Jung se depara com a seguinte problemática: o símbolo de Cristo não possui a totalidade que a definição psicológica do si-mesmo exige. A figura dogmática do deus não inclui o aspecto noturno”. Desse modo, em nível psicológico, a figura de Deus e de Cristo é atribuída à representação da luz da consciência, já o lado do mal, da escuridão é retirado da figura de Deus e de Cristo e depositado na figura do Anticristo. Este fato torna-se uma problemática, pois entendendo Deus e Cristo como uma reencarnação humana, um deus-homem, e assim como uma representação da totalidade do si-mesmo, nele deveria estar contido seu oposto; luz e sombra reunidas na representação de Deus e de Cristo. Conforme postulações desse autor,

se reconhecermos um paralelo da manifestação psicológica do si-mesmo na figura tradicional de Cristo, o Anticristo corresponde à sombra do simesmo, isto é, à metade obscura da totalidade do homem, que não deve ser julgada com demasiado otimismo. [...] A luz e a sombra formam uma unidade paradoxal no si-mesmo empírico. Na concepção cristã, pelo contrário, o arquétipo em questão está irremediavelmente dividido em duas metades inconciliáveis, porque o resultado final conduz a um dualismo metafísico, isto é, a uma separação definitiva entre o Reino celeste e o mundo de fogo da condenação. (JÜN, 1986, p. 39).

Segundo Jung (1988), psicologicamente, este dualismo metafísico, no qual o Anticristo adquire uma forma como Cristo e assim em contraposição a ele, somente existiu mítica e arquetipicamente com a ascensão do Cristianismo, antes disso no Antigo testamento, o demônio era considerado um dos filhos de Deus e próximo a Javé. Assim, na representação dogmática teológica cristã (e não arquetipicamente), Cristo torna-se um deus perfeito e sem mácula, e nele é retirada toda representação da Sombra, do Mal; e retribuída ao demônio como forma de um complemento da representação da totalidade. Desse modo, a imagem do demônio aparece, arquetipicamente, como um complemento psíquico, com finalidade de restaurar o equilíbrio. “A vinda do Anticristo não é apenas uma predição de caráter profético, mas uma lei psicológica inexorável, cuja existência levou o autor das Cartas [de João], sem que ele soubesse, a certeza, da enantiodromia vindoura”. (JUNG, 1986, 
p. 40). Sendo assim, a simbologia Cristã representaria uma constatação no campo da psicologia por apresentar a complementação de Cristo, na figura do demônio como forma de compensação da unilateralidade presente.

Em termos psicológicos, a enantiodromia designaria a manifestação do oposto inconsciente no decorrer do tempo. Este fenômeno ocorre na presença de uma atitude extremamente unilateral da vida psíquica consciente. Forma-se, então, com o tempo, uma contraposição inconsciente tão forte quanto, o que provoca uma interrupção da direção consciente. (RICHTER, 2005, p. 82).

Psicologicamente, trata-se de adotar o entendimento de que Deus e Cristo seriam perfeitos, sem mácula, representantes da luz e da consciência, e o demônio exerceria a função da representação da sombra, imperfeito e do inconsciente. Entramos, portanto no âmbito da discussão acerca da doutrina da Privatio Boni, que considera o mal uma privação do bem. "Com efeito, de acordo com a doutrina da Igreja Católica, o mal é meramente a "carência acidental de uma perfeição". (JUNG, 1986, p. 38). Sendo assim, “podemos dizer que a própria concepção da privatio boni constitui uma forma de contornar esta problemática3: Deus representa uma totalidade e ao mesmo tempo não necessita incluir o princípio do mal”. (RICHTER, 2005, p. 82). Surge, então, uma premissa da doutrina da Igreja “omnebonum a Deo, omnemalumabhomine" [Deus é bom e todo homem é mau], baseada em Taciano, e também defendida por Teófilo de Antioquia (ambos do século II), o mal é a ausência do bem, na qual o bem provém de Deus e o mal provém do homem (JUNG, 1986).

Outros autores também enfatizam o entendimento da figura de Deus e de Cristo como perfeita, Summum Bonum; e o demônio como a privação do bem, privatio boni. Assim, o conceito de Summum Bonum, ligado ao de privatio boni, aparece nos escritos de Basilio Magno (330-379), Dionísio Areopagita (segunda metade do século IV) e em Agostinho (séculos IV/ V). (JUNG, 1986). Percebemos

${ }^{3}$ Contudo, mesmo com a doutrina da Privatio boni, continua a unilateralidade da imago Dei, pois ainda não considera nela o lado do mal. 
que esses autores negam a realidade e a substancialidade do mal4. Jung afirma que em nível psicológico, é inadmissível aceitar tal proposição, pois é necessário conceber o mal também na figura Deus, sendo assim, há uma unilateralidade da imago Dei no Cristianismo. Segundo Richter,

Jung não está criticando a ideia em questão num sentido teológico, e sim somente enquanto esta se choca com as observações do empirista. Segundo a experiência psicológica, bem e mal constituem um par de opostos de um julgamento moral que se origina no próprio homem. Um determinado julgamento, porém, só ocorre na medida em que o seu oposto é possível. (RICHTER, 2005, p. 84).

Segundo Jung (1986), psicologicamente, bem e mal são duas instâncias diferentes. Sendo assim, o mal não é apenas o bem diminuído, mas sim possuidor de uma autonomia em si tanto quanto o bem. "A ideia da Privatio Boni representaria, assim, uma negação da oposição entre Bem e Mal. Desconsiderando a existência do Mal, o Bem não passaria de algo vago, jamais se depararia com um adversário real, diante do qual precisasse firmar a sua posição”. (RICHTER, 2005, p.85). Conforme Jung (1988) este entendimento do mal como, apenas, sendo o bem diminuído é inadmissível a uma observação criteriosa da psicologia. Pois, no modelo cristão, aristotelicamente (ABBAGNANO, 2007), o mal não tem substância, apenas, é um acidente, ou seja, não existe por si só, como o Bem.

Dado que a Psicologia não é Metafísica, não se pode deduzir qualquer dualismo metafísico da constatação que ela faz da existência de contrários correlatos, nem imputá-los à Psicologia. A Psicologia sabe que os opostos correlatos constituem condições imprescindíveis e inerentes ao ato de conhecimento, pois sem eles seria impossível qualquer tipo de diferenciação. (JUNG, 1986, p. 57).

Assim, a ideia da Privatio boni exclui a autonomia em si do demônio, rebaixando-a apenas, como a ausência do Bem, contradizendo a perspectiva psicológica dos opostos. "O Diabo, como pessoa autônoma e eterna, corresponde mais ao seu papel de Adversário de Cristo à Psicológica do Mal”. (JUNG, 1988, p. 169).

\footnotetext{
${ }^{4}$ Conforme Bonfatti (2000, p.78), “a Teologia Cristã, ao adotar para si estas doutrinas, enfatiza a seguinte lógica: Deus produz somente o bem e o mal não foi criado por Ele, porque Ele é o Summum Bonum e d'Ele só pode vir o bem, já o mal vem do homem sendo este uma privação ou diminuição do bem - Privatio boni. [...] A realidade do mal foi, há bastante tempo, negada pela Teologia Cristã, visto que, segundo ela, o mal é posterior ao bem, não possui substância, existência própria e assim até não existe".
} 
Nesta direção, Jung faz uma análise da psicológica da doutrina da privatio boni, e questiona se é possível cogitá-la numa perspectiva arquetípica. Contudo, por entender que ela exclui a autonomia do mal, não poderia ser vista como uma forma psicológica, mas, apenas, como uma questão histórica, tardia da civilização humana, a partir do Cristianismo. Na doutrina da privatio boni, “a estrutura dos opostos se apresentaria de maneira vacilante e pouco clara na doutrina em questão, ao contrário do jogo dos opostos de natureza arquetípica, que se impõe de forma incondicional e inquestionável” (RICHTER, 2005, p. 85). Nos termos de Jung,

parece-me, no entanto, que o material empírico existente não permite pelo menos até onde me ensina a experiência - uma conclusão decisiva que me indicasse um condicionamento arquetípico da privatio boni. As definições morais bem claras são - se não me engano - aquisições recentes do homem civilizado. Por isso ainda são frequentemente nebulosas e incertas, ao contrário de outros pares de contrários que são indubitavelmente de natureza arquetípica e representam condições básicas para o conhecimento consciente em geral, como o platônico [o mesmo e o outro]. (JUNG, 1988, p. 309).

Assim, entendendo que a concepção cristã não incorpora a questão do mal na figura de Deus e Cristo (que é uma das representações Cristã de Deus), e não entende o Mal como oposição, mas, apenas, a ausência do Bem, não é possível atribuir a Deus e Cristo como representação da totalidade do si-mesmo, por ele não conter em si o aspecto oposto. Conforme Richter,

no entanto, quando consideramos o conceito do si-mesmo mais estritamente a partir de sua definição psicológica, percebemos que este expressa uma antinomia, devido ao fato de exprimir a soma dos conteúdos conscientes e inconscientes. Nesse sentido, as qualidades atribuídas a [Deus, e] Cristo precisam ser complementadas pelos seus contrários. Como homem histórico, Cristo seria único e singular; como figura divina, universal e eterno. O mesmo ocorreria com o si-mesmo: como individualidade este é único e singular; como símbolo arquetípico, universal e eterno. A concepção teológica que descreve [Deus, e] Cristo como simplesmente bom e espiritual precisaria [, psicologicamente,] ser inteirada com os atributos: mau, material ou ctônico. (RICHTER, 2005, p. 86).

Faz-se necessário, novamente, ressaltar, aqui, a visão superficial em que Jung é defensor das religiões. Essa sua linha de raciocínio sobre a questão do mal, no cristianismo, configura-se em uma consideração, extremamente, contrária aos 
preceitos religiosos cristãos, mesmo que consideremos que os apontamentos junguianos sejam de ordem, estritamente, psicológica e não teológica.

Além da questão do Cristo, há também a problemática da imago dei em relação ao mal. É neste sentido que Jung (1988), faz uma análise psicológica do dogma da Trindade, por entender que na figura da Divindade, há uma exclusão do mal, da matéria e do feminino. Sendo assim, em nível psicológico é impossível pensar a figura da divindade como representação do si-mesmo, somente é possível pensar em nível teológico, pois como visto aqui, anteriormente, Jung (1986) entende que o dogma da Trindade, antes de ser visto a nível teológico é arquetípico. Assim, a divindade trinitária remete a questão arquetípica e, não é uma exclusividade, do Cristianismo, pois encontramos a concepção trinitária da divindade também na Babilônia, Egito e Grécia (SILVEIRA, 1981). Antes de ser religiosa, a divindade trinitária é uma elaboração das instancias arquetípicas e coletivas e, enquanto tal, tende a integrar os conteúdos opostos.

Desse modo, em nível religioso o dogma da trindade, a figura de Deus é perfeita e plena e a representação do mal, do feminino e da matéria estão para além da trindade, está direcionada ao demônio, cujo fato não faz parte da trindade. Sendo assim, a figura de unilateral Deus não seria uma representação da totalidade do si-mesmo considerando esse como união dos opostos, unium oppositorum. Sendo assim, deveria conter nele tanto a representação do Bem como do Mal, do Masculino como do Feminino, e do Espírito como da Matéria, ou seja, tanto a figura de Cristo como a do Demônio (JUNG, 1986).

Segundo Jung, há autores da Igreja que apontam não ser possível deixar de pensar na figura de Satanás, pois este teria uma autonomia em si, e está presente a partir do dogma da Trindade, no qual ele seria o opositor de Deus. "No mistério de Deus, em três pessoas, se revela uma nova liberdade divina, nas profundezas de seu ser, que também possibilita a ideia de um demônio pessoal junto a Deus e contra ele.” (JUNG, 1988, p. 58-59). Sendo assim, Jung apresenta a importância psicológica de incluir o demônio na questão da figura de Deus não sendo apenas 
três, mas quatro, devido o demônio constituir em si características, semelhantes a Cristo, fato este que a Teologia apresenta na figura de Deus apenas a característica trinitária. Já a psicologia junguiana entende o aspecto quaternário, como representação mais adequada do si-mesmo, englobando tanto a trindade, quanto o demônio, formando assim, a totalidade projetada do si-mesmo.

A inclusão do demônio na quaternidade não é em absoluto uma especulação moderna ou um produto inaudito do inconsciente. Encontramos num filósofo da natureza e médico do século XVI, Gerardus Dorneus, uma discussão pormenorizada em que contrapõe o símbolo da Trindade à quaternidade, sendo esta última atribuída a demônio. (JUNG, 1988, p. 59).

Jung (1986) entende que o simbolismo central cristão é o dogma da Trindade como representação de Deus. Contudo, o simbolismo cristão, em nível psicológico e não teológico, seria incompleto por não englobar os aspectos do mal, feminino e a matéria, devendo assim, ter uma reconciliação com a sombra, pois o diabo não é acolhido na forma trinitária de representação de Deus. Jung afirma que isto ocorre devido ao fato do Cristianismo constituir-se de sistema religioso monoteísta, assim o que se opõe a Deus não pode estar contido nele próprio, está aquém de si. Como já visto, anteriormente, no Antigo Testamento Javé teria uma bipolaridade, contendo em si, tanto características boas quanto más. Já no Novo Testamento, Deus assumiria as características de bem, masculino e luminoso; e o demônio os aspectos do mal, feminino e sombrio. (RICHTER, 2005).

Desse modo, a imago dei cristã representa uma totalidade incompleta do simesmo, pois falta a ela o lado escuro da sombra, o material e o feminino. Isto compromete em si o processo de individuação. Conforme Bonfatti (2007, p. 93), "através da imago dei cristã, estaríamos nos relacionando de forma incompleta com o si-mesmo. Esta relação incompleta afetaria o processo de crescimento psicológico - que Jung chamou de individuação”.

Portanto, para se pensar o Cristianismo como uma perspectiva psicológicoarquetípica, e não teológica, dever-se-ia conceber o "demônio" como parte da representação da totalidade da totalidade do si-mesmo. Conforme Jung, 
como adversário de Cristo, deveria ocupar uma posição antinômica correspondente e ser também um "Filho de Deus". Isto nos levaria diretamente a certas concepções gnósticas segundo as quais o Diabo, que chamavam de Satanael, era o primeiro Filho de Deus e Cristo o segundo. Outra consequência lógica seria a abolição da forma trinitária e sua substituição por uma quaternidade. (JUNG, 1988, p. 170).

Contudo, mesmo que Jung (1986) identifique que a divindade trinitária do Cristianismo é incompleta (já que entendemos esta como uma elaboração arquetípica, pois não engloba o quarto elemento; o mal, a matéria e o feminino), mas essa é uma representação histórica, que, inexoravelmente, daqui a alguns séculos, provavelmente do ponto de vista psicológico, será provavelmente modificada. Como vimos, vale ressaltar que um novo dogma surge como fruto de uma elaboração coletiva e não simplesmente como uma questão teológica. Assim o dogma da ascensão de Maria é uma elaboração coletiva apontando para uma representação de uma necessidade psíquica coletiva.

Arquetípica e historicamente, apesar de não ser uma admissão da doutrina Católica, Jung (1988) aponta que o modelo Trinitário é substituído para uma quaternidade, somente a partir da Assunção de Maria (SANTA FÉ, 1950). A partir da divindade de Maria surge a possibilidade de uma quaternidade, no qual o corpo de Maria é elevado aos céus juntamente com sua alma, como ocorre com a figura de Cristo. Entretanto, o corpo de Maria é mais material, vinculado a uma realidade relacionada ao espaço e tempo. Segundo Jung,

a iconologia da Idade Média, desenvolvendo especulações a respeito da (mãe de Deus), imaginou um símbolo quaternário, mediante as representações da coroação de Maria, e o introduziu, por assim dizer de mansinho no lugar da Trindade. A Assumptio Beatae Maria Virginis [Assunção da Bem-Aventurada Virgem Maria] significa que a alma de Maria foi introduzida no céu juntamente com o corpo, e é uma doutrina admitida pela Igreja, embora não tenha sido fixada como dogma. Cristo foi elevado também aos céus em corpo e alma, mas aqui existe algo bastante diferente, pois Cristo é Deus, o que não se pode dizer de Maria. No caso desta, tratar-se-ia de um corpo muito mais material, isto é, de uma realidade ligada ao espaço e ao tempo, o que não é precisamente o caso de Cristo. (JUNG, 1988, p. 170-171). 
Com o reconhecimento teológico da Assunção de Maria integra-se, psíquica e arquetipicamente, a questão da quaternidade à figura de Deus e também o mal, já que este está associado à matéria e ao princípio feminino. A matéria é o oposto do espírito e está relacionada com o diabo. Desta forma ao integrar na figura de Deus o quarto elemento, o mal, a matéria e o feminino, este a nível psicológico torna-se, por excelência, uma forma de representação da imago dei e do si-mesmo. Conforme Jung,

a Assumptio Mariae significa uma preparação, não apenas para a divindade de Maria, mas também para a quaternidade. Ao mesmo tempo, a matéria é transposta para o reino da metafísica e juntamente com ela o princípio corruptor deste mundo, o Mal. Pode-se considerar a matéria como originariamente pura e, em princípio, capaz de pureza, mas isto não excluiria o fato de que a matéria indica, pelo menos, a certeza dos pensamentos de Deus, possibilitando, por conseguinte, o processo de individuação. (JUNG, 1988, p. 171)5.

Assim, pode-se entender a importância que é concedida ao fenômeno religioso e às religiões em geral na psicologia junguiana. Ao identificar as religiões como manifestações psíquicas do ser humano, sem negar a perspectiva teológica, Jung (1988) as entende como caminhos que podem levar ao autoconhecimento. Deste modo, do ponto de vista psicológico, as representações religiosas seriam analogias das experiências psíquicas do ser humano.

Portanto, a experiência religiosa e os símbolos religiosos contidos nas religiões servem com formas de expressão simbólica da humanidade. Sendo assim a experiência religiosa pode ser um dos caminhos possíveis para individuação. Contudo se a religião não for uma representação simbólica, permitindo que o ego tenha consciência dos conteúdos do inconsciente, esta atrapalhará o processo de individuação do indivíduo. (JUNG, 1988).

\footnotetext{
${ }^{5}$ Vale novamente ressaltar aqui a visão superficial de que Jung seja o defensor das religiões. Essa sua linha de raciocínio sobre a questão da quaternidade da imago dei (uma representação que inclui o mal, a matéria e o feminino à imago dei) também se configura em uma consideração extremamente contrária aos preceitos religiosos cristãos, mesmo que consideremos que os apontamentos junguianos sejam de ordem estritamente psicológica, e não teológica.
} 
Identificamos, então, a importância que Jung (1988) dá à religião, como uma expressão simbólica da experiência psicológica arquetípica. Ele identifica a religião como um dos caminhos possíveis para individuação, contudo não apenas o único caminho. Contudo, entendemos também que a religião quando não vivenciada de forma simbólica, e não permitindo que o ego tenha uma ampliação de sua consciência, ela também poder ser fonte de paralização do processo de desenvolvimento do ego e do processo de individuação. Consequentemente, a religião pode se tornar um fator para a patologização.

\section{Conclusão}

O esforço feito junto ao leitor foi de tentar levá-lo a compreender a visão da psicologia de Carl Gustav Jung acerca da religião. Nesse empenho, esperamos ter sido claros ao tentar elucidar sua perspectiva exclusivamente psicológica e não metafísica ou transcendental como tantas vezes Jung é acusado.

O que tentamos apontar é que ritos, rituais, experiências e dogmas religiosos são vistos pela psicologia junguiana como experiências psicológicas arquetípicas que podendo se tornar simbólicas ou não. Essas possibilidades, como visto, dependem da atitude do ego, em relação às estas experiências. Caso sejam simbólicas, facilitam a elaboração do ego dos conteúdos arquetípicos. Assim, se o ego se relacionar com a religião, esta pode se tornar uma experiência simbólica facilitando a assimilação de conteúdos psíquicos, pois se entende que os rituais e dogmas presentes permitirão o contato com experiências arquetípicas de forma positiva e enriquecedora. Contudo se o ego, ao entrar em contato com tais experiências não conseguir simbolizar, aí ocorrerá uma invasão arquetípica ocasionando sérios prejuízos à sua integridade, resultando em psicopatologias.

Assim sendo, entendemos que a perspectiva da teoria junguiana apresentase como uma possível chave de leitura para compreender a religião como uma função psíquica presente em diversas culturas. Enquanto uma forma de expressão simbólica, ela se revela significativa como um dos possíveis, não o único, caminhos 
para o desenvolvimento psicológico do indivíduo, conduzindo para o processo de individuação.

Tal visão junguiana aparentemente favorável à religião não desconsidera que a mesma também possa se tornar um campo privilegiado de experiências psicopatológicas, quando não exerce uma função simbólica e a experiência arquetípica se torna imediata e invasiva ao ego. Mais que isso, viu-se também que há o impedimento do desenvolvimento do ego, conduzindo o indivíduo, por conseguinte, à condição psíquica de não individuação ou imaturidade psicológica.

\section{REFERÊNCIAS}

ABBAGNANO, N. Dicionário de filosofia. 5. ed. São Paulo: Martins Fontes, 2007.

BAIR, D. Jung: uma biografia. São Paulo: Globo, 2006. v. 1.

BONFATTI, P. F. A questão do mal: uma abordagem psicológica junguiana. Rhema, v. 6, n. 22, p. 69-98, 2000.

BONFATTI, P. F. Psicologia sine tempore: uma análise dos conceitos de arquétipos, inconsciente coletivo e si-mesmo, na teoria de Carl Gustav Jung. 2007. Tese (Doutorado em Psicologia) - Pontifícia Universidade Católica do Rio de Janeiro, Rio de Janeiro, 2007.

CLARKE, J. J. Em busca de Jung: indagações históricas e filosóficas. Rio de Janeiro: Ediouro, 1993.

JUNG, C. G. Aion: estudos sobre o simbolismo do si-mesmo. Petrópolis: Vozes, 1986.

JUNG, C. G. Cartas I. Petrópolis: Vozes, 2003.

JUNG, C. G. Psicologia da religião ocidental e oriental. Petrópolis: Vozes, 1988.

JUNG, C. G. Psicologia e alquimia. Petrópolis: Vozes, 1991.

JUNG, C. G. Símbolos da transformação. Petrópolis: Vozes, 2011.

OTTO, R. O sagrado. Lisboa: Edições 70, 1992.

RICHTER, L. K. A concepção de religião no pensamento de C. G. Jung. 2005.

Dissertação (Mestrado em Psicologia) -Pontifícia Universidade Católica do Rio de Janeiro, Rio de Janeiro, 2005. 
SANTA FÉ. Constituição apostólica do Papa Pio XII Munificentissimus Deus: sobre a definição do dogma da assunção de Nossa Senhora em corpo e alma ao céu. Novembro de 1950. Disponível em: http://w2.vatican.va/content/piusxii/pt/apost_constitutions/documents/hf_p-xii_apc_19501101_munificentissimusdeus.html. Acesso em: 2 abr. 2019.

SILVEIRA, N. Jung: vida e obra. Rio de Janeiro: Paz e Terra, 1981. 